\title{
PERUBAHAN pH SALIVA SEBELUM DAN SESUDAH BERKUMUR AIR REBUSAN JAHE MERAH PADA MASYARAKAT DI KELURAHAN LOMPO RIAJA KECAMATAN TANETE RIAJA KABUPATEN BARRU
}

\author{
Ernie Thioritz, Muhammad Saleh
}

\begin{abstract}
ABSTRAK
Saliva adalah suatu cairan oral yang kompleks yang terdiri dari atas campuran sekresi dari kelenjar ludah besar dan kecil yang ada pada mukosa mulut. Saliva juga mempengaruhi pH mulut, jika aliran saliva berkurang ataupun hilang maka karies akan terjadi. Pencegahan dapat dilakukan dengan menggunakan metode mekanis maupun kimiawi. Metode kimia yang dipakai adalah menggunakan obat kumur yang ada di pasaran. Penggunaan obat kumur antiseptik kimiawi dalam jangka panjang bisa menyebabkan efek yang tidak diinginkan, misalnya hipersensitivitas, gangguan sekresi kelenjar ludah, dan lain-lain. Sehingga diperlukan cara untuk memelihara keseimbangan $\mathrm{pH}$ saliva dengan penggunaan larutan kumur yang lebih aman dan tanpa efek samping. Jahe merah merupakan tanaman rempah yang digunakan sebagai bahan minuman, bumbu masak serta obat-obatan tradisional. Jahe merah memiliki kandungan oleoresin dan minyak atsiri yang dapat mempengaruhi $\mathrm{pH}$ saliva. Sehingga jahe merah dapat digunakan sebagai obat kumur alami. Tujuan dari penelitian ini adalah untuk mengetahui perubahan $\mathrm{pH}$ saliva sebelum dan sesudah berkumur rebusan air jahe merah pada masyarakat Kel. Lompo Riaja, Kec. Tanete Riaja, Kab. Barru. Populasi dalam penelitian ini adalah masyarakat di Kel. Lompo Riaja, Kec. Tanete Riaja Kab. Barru, dengan jumlah sampel sebanyak 30 orang yang memenuhi kriteria inklusi. Jenis penelitian yang dilakukan adalah deskriptif kuantitatif dengan metode eksperimen. Desain penelitian dengan pre post and post test group design. Analisa data untuk penelitian ini adalah dengan uji statistik Paired T-Test. Hasil analisa data memperoleh nilai $p<0,05$ yaitu 0,000. Yang menunjukkan bahwa terdapat perubahan $\mathrm{pH}$ saliva sebelum dan sesudah berkumur air rebusan jahe merah.
\end{abstract}

Kata Kunci: Air Rebusan, Jahe Merah, pH Saliva

\section{PENDAHULUAN}

Kesehatan gigi dan mulut merupakan

hal yang sangat penting karena gigi dan gusi yang rusak dan tidak dirawat akan menyebabkan rasa sakit, gangguan pengunyahan dan dapat mengganggu kesehatan tubuh lainnya. Mulut merupakan suatu tempat yang sangat ideal bagi perkembangan bakteri. Bila tidak dibersihkan dengan sempurna, sisa makanan yang terselip bersama bakteri akan bertambah banyak dan membentuk koloni.

Dalam keadaan normal, gigi geligi secara terus-menerus terendam dalam saliva sampai sebanyak $0,5 \mathrm{ml}$ yang akan membantu melindungi gigi, lidah, membran mukosa mulut dan orofaring. Saliva adalah suatu cairan oral yang kompleks yang terdiri dari atas campuran sekresi dari kelenjar ludah besar dan kecil yang ada pada mukosa mulut. Saliva juga mempengaruhi $\mathrm{pH}$ mulut, jika aliran saliva berkurang ataupun hilang maka karies akan terjadi (Kidd dan Bechal, 1991).
Berdasarkan Riset Kesehatan Dasar (RISKESDAS) tahun 2013 menyatakan sebesar $25,9 \%$ penduduk Indonesia mempunyai masalah gigi dan mulut dalam 12 bulan terakhir (potential demand). Menjaga kebersihan gigi dengan cara mengurangi kondisi asam pada rongga mulut dan menjaga $\mathrm{pH}$ saliva dalam rentang normal dapat mencegah berbagai masalah gigi khususnya karies gigi yang disebabkan oleh bakteri Streptococcus mutans.

Kidd et al. (2010) menuliskan dalam bukunya yang dikutip oleh Ratnasari (2015), pencegahan dapat dilakukan dengan menggunakan metode mekanis maupun kimiawi. Metode kimia yang dipakai adalah menggunakan obat kumur yang ada di pasaran. Metode yang paling umum dalam menjaga kebersihan rongga mulut selama ini adalah dengan menggosok gigi. Namun untuk beberapa kasus, terutama kasus penyakit karies gigi, penggunaan obat kumur sangat diperlukan. Menggosok gigi saja kurang efektif untuk mengurangi akumulasi koloni bakteri 
Streptococcus mutans yang dapat berujung pada pembentukan karies gigi. Berkumur dengan obat kumur dapat menghilangkan bakteri di sela-sela gigi yang tidak terjangkau oleh sikat gigi. Mekanisme kerja obat kumur adalah membersihkan rongga mulut secara mekanik dan kimiawi. Sifat antibakteri obat kumur terutama ditentukan oleh bahan aktif yang terkandung di dalamnya. Bahan-bahan aktif dalam obat kumur memiliki kelebihan dan kekurangan. Penggunaan obat kumur antiseptik kimiawi dalam jangka panjang bisa menyebabkan efek yang tidak diinginkan, misalnya hipersensitivitas, gangguan sekresi kelenjar ludah, dapat merubah keseimbangan kehidupan bakteri flora normal rongga mulut, serta dapat menimbulkan noda pada gigi.

Pada umumnya obat kumur mengandung 5 - $25 \%$ alkohol. Alkohol dimasukkan dalam obat kumur untuk beberapa kegunaan, antara lain sebagai antiseptik, memperpanjang masa simpan obat kumur, mencegah pencemaran mikroorganisme dan sebagai pelarut. Namun kandungan alkohol dalam obat kumur ini menyebabkan individuindividu tertentu tidak dapat menggunakan obat kumur yang mengandung alkohol, seperti anakanak, ibu hamil/menyusui, pecandu alkohol, pasien-pasien yang menggunakan metronidazole, dan pasien xerostomia. Kandungan alkohol yang terdapat dalam obat kumur juga dapat meningkatkan resiko kanker rongga mulut, terutama bila pemakaian terusmenerus (Sari, Cholil \& Sukmana, 2014). Sehingga diperlukan cara untuk memelihara keseimbangan $\mathrm{pH}$ saliva dengan penggunaan larutan kumur yang lebih aman dan tanpa efek samping.

Jahe merah merupakan tanaman rempah yang digunakan sebagai bahan minuman, bumbu masak serta obat-obatan tradisional. Jahe merah memiliki kandungan minyak atsiri yang dapat mempengaruhi $\mathrm{pH}$ saliva. Indonesia kaya akan berbagai macam rempah-rempah, salah satunya yaitu jahe merah. Pada penelitian terdahulu, Harahap dkk (2017) telah melakukan penelitian tentang perubahan $\mathrm{pH}$ saliva sebelum dan sesudah berkumur air rebusan jahe merah pada Mahasiswa Fakultas Kedokteran Gigi Universitas Syiah Kuala angkatan 2016.

Menurut Thylstrup \& Feyerskov (1996), pengertian saliva pada umumnya adalah cairan rongga mulut yang dihasilkan oleh tiga pasang kelenjar saliva besar, yaitu parotis, submandibularis, dan sublingualis, kelenjat saliva minor, dan cairan dari sulkus gingiva. Saliva ini terdapat sebagai lapisan setebal 0,1 $0,01 \mathrm{~mm}$ yang melapisi seluruh permukaan rongga mulut dan selalu bergerak. Kecepatan pergerakan lapisan inilah yang menentukan distribusi material dan eliminasi bahan yang tidak digunakan dari rongga mulut. Namun kecepatan ini sangat bergantung pada jumlah dan komposisi serta pergerakan pipi, bibir, dan lidah. Pada seseorang kecepatan juga bervariasi bergantung tempatnya dalam rongga mulut (Sundoro, 2007).

Cairan mulut tersusun atas cairan sekresi kelenjar ludah dan eksudat serum lewat cairan krevikular. Secara kuantitatif sokongan terbesar pada saliva diberikan oleh kelenjarkelenjar saliva: glandula parotis, glandula submandibularis dan glandula sublingualis. Dari masing-masing kelenjar ludah ini manusia memiliki satu kira dan satu kanan. Disamping itu masih banyak sekali terdapat kelenjar saliva kecil tambahan (kelenjar aksesori) di dalam mukosa pipi (bukal), bibir (labial), lidah (lingual) dan langit-langit (palatinal). Jumlah seluruhnya diperkirakan 450 - 750. Sifat kelenjar saliva dan sekresinya ditentukan oleh tipe sel sekretori yaitu serus, seromukus dan muku. Saliva serus menunjukkan saliva yang encer dan saliva mukus merupaka saliva yang pekat (Amerongen, Michels, Roukema \& Veerman, 
1991).

Screebny dkk (1992) dalam bukunya mengemukakan meskipun 99\% dari saliva adalah air, sisanya merupakan komponen yang terdiri dari bahan anorganik, bahan organik, dan molekul-molekul makro termasuk bahan-bahan antimikroba, sangat penting fungsinya untuk menjaga integritas jaringan-jaringan mulut (Sundoro, 2007). Komposisi saliva di rongga mulut ditentukan oleh tingkatan sekresi dari sel acinar ke sistem duktus yang menyebabkan peningkatan konsentrasi garam dan osmoluritas seiring dengan peningkatan laju aliran saliva (Almeda, 2008; Kasuma, 2015). Dawes (1996) menuliskan dalam bukunya, tetapi komposisi saliva juga sangat bergantung pada berbagai faktor, antara lain jenis kelenjar yang menghasilkannya. Di samping itu macam, lama, dan jenis rangsangan juga sangat memengaruhi. Demikian pula kecepatan sekresi, diet, hormon, ritme biologis, latihan, beberapa penyakit, dan obat-obatan (Sundoro, 2007).

Minasari (1999) mengemukakan, dalam saluran pencernaan terdapat perbedaan $\mathrm{pH}$ yang besar di antara berbagai cairan pencernaan makanan, cairan mulut hampir netral, getah lambung sangat asam, getah pankreas dan getah usus agak alkalis masingmasing menghasilkan lingkungan optimal bagi aktifitas enzim pencernaan yang ada (Rezkiah, 2008).

Etriyani (2006) dalam bukunya menjelaskan besarnya $\mathrm{pH}$ mulut tergantung dari saliva sebagai buffer yang mereduksi formasi plak. Pembentukan asam oleh bakteri di dalam plak maka akan terjadi penurunan $\mathrm{pH}$. Dengan adanya penurunan $\mathrm{pH}$ akan menyebabkan kadar asam menjadi tinggi di dalam mulut akibatnya $\mathrm{pH}$ saliva menjadi asam. Derajat keasaman $\mathrm{pH}$ dan kapasitas buffer saliva ditentukan oleh susunan kuantitatif dan kualitatif elektrolit di dalam saliva ditentukan oleh susunan bikarbonat, karena susunan bikarbonat sangat konstan dalam saliva dan berasal dari kelenjar saliva. Derajat keasaman saliva dalam keadaan normal antara 5,6 - 7,0 dengan ratarata $\mathrm{pH}$ 6,7. Beberapa faktor menyebabkan terjadinya perubahan pada $\mathrm{pH}$ saliva antara lain rata-rata kecepatan saliva, mikroorganisme rongga mulut, dan kapasitas buffer saliva (Situmeang, 2017).

Volume saliva yang dihasilkan oleh setiap orang berkisar 0,5 - $1 \mathrm{~L}$ per hari. Saliva seseorang dalam keadaan normal memiliki $\mathrm{pH}$ berkisar antara 6,7 - 7,3, dengan $\mathrm{pH}$ saliva normal rata-rata 6,8 dan $\mathrm{pH}$ kritis $<5,5$ (Harahap dkk, 2017).

Karies gigi merupakan penyakit infeksi yang melibatkan empat faktor utama yaitu host, substrat, mikroorganisme dan waktu. Penyakit ini terjadi akibat adanya proses demineralisasi yang terus-menerus pada jaringan keras gigi oleh asam organik yang berasal dari makanan maupun minuman yang mengandung gula dan difermentasikan oleh bakteri. Proses demineralisasi berlangsung ketika $\mathrm{pH}$ saliva di bawah 5,5 atau bersifat asam. Pada keadaan ini bakteri asidogenik penyebab karies gigi, seperti Streptococcus mutans dan Lactobacillus berkembang baik dengan cepat (Kusumawardani dkk, 2017).

Peranan dari saliva diantaranya menjaga keseimbangan buffer, membantu keseimbangan cairan dan membantu sebagai reseptor rasa dalam rongga mulut, yang mana peranan ini untuk menjaga keseimbangan ekosistem rongga mulut (Harahap dkk, 2017)

Jahe (Zingiber officinale Rosc) merupakan tanaman rempah dan obat. Jahe juga dikenal sebagai tanaman multiguna, di antaranya sebagai tanaman obat tradisional, jamu, bahan dasar minuman dan industri makanan, serta bumbu masak (rempahrempah). Pada saat ini tanaman rempah dan obat-obatan atau sering disebut biofarmaka, semakin banyak dimanfaatkan oleh masyarakat, 
terutama untuk bahan baku obat maupun industri (Lestari, 2017; Setyaningrum \& Saparitno, 2016; Setyawan, 2015; Gendrowati, 2018).

Di Indonesia sendiri tanaman jahe sudah ada sejak zaman dahulu kala. Bahkan beberapa alasan mengapa dahulu negaranegara Eropa berdatangan ke Indonesia adalah mendapatkan rempah berkhasiat tersebut. Namun demikian, ternyata tanaman jahe bukanlah asli dari Indonesia. Para penelitian sejarah taksonomi dan morfologi tumbuhan meyakini bahwa asal mula tanaman jahe berasal dari tanah India (Lestari, 2017).

Menurut Nilkolai Ivanovich Vavinov, seorang pakar botani asal Uni Soviet mengungkapkan bahwa meskipun tanaman jahe sudah banyak dimanfaatkan sebagai tanaman obat oleh masyarakat China sejak era Confusius (551 - 479 SM), tetapi awal mula tanaman jahe sebenarnya dari Negara India (Lestari, 2017).

Tanaman jahe itu sendiri yaitu Zingiber officinale yang terdiri dari kata "Zingiber" yang berasal dari bahasa sansekerta "Singibera" yang bermakna bentuk seperti tanduk, untuk menamakan benruk rimpang dari jahe yang berbentuk seperti tanduk rusa. Sedangkan Officinale berasal dari Bahasa latin "Officinal" yang bermakna pengobatan. Berdasarkan makna tersebut, tanaman jahe dari dulu dikenal sebagai tanaman rempah atau obat-obatan yang mampu menyembuhkan berbagai macam penyakit (Lestari, 2017).

Penyebaran tanaman jahe bermula melalui jalur perdagangan yang dibawa oleh para pedagang asal China dan Persia yang melakukan perdagangan lintas negara dan benua hingga melalui jalur sutra, yang akhirnya sampai ke Indonesia. Kini tanaman jahe tersebar hampir di seluruh wilayah Indonesia (Lestari, 2017).

Jahe banyak digunakan untuk ramuan obat tradisonal, obat-obatan, jamu, bumbu masak, hingga bahan baku industri makanan dan minuman. Manfaat dari jahe ini diperoleh karena adanya kandungan minyak atsiri pada rimpang jahe. Minyak atsiri adalah sejenis minyak yang mudah menguap, yang tersusun atas senyawa zingiberen $\left(\mathrm{C}_{2} \mathrm{H}_{24}\right)$ dan zingiberal $\left(\mathrm{C}_{12} \mathrm{M}_{26} \mathrm{O}_{2}\right)$ (Lestari, 2017).

Lestari (2017) dalam bukunya mengemukakan bahwa senyawa lain yang membuat rimpang jahe berasa pedas dan agak pahit adalah oleoresin (faxed oil). Komponennya yaitu senyawa gingerol $\left(\mathrm{C}_{14} \mathrm{H}_{26} \mathrm{O}_{4}, \mathrm{C}_{18} \mathrm{H}_{28} \mathrm{O}_{5}\right)$, shongaol $\left(\mathrm{C}_{7} \mathrm{H}_{24} \mathrm{O}_{3}\right)$, dan resin. Di samping itu, minyak jahe juga mengandung senyawasenyawa seperti pinen, kamfen, felandren, sineol, metilheptanon, linalol, bormeol, sitral, $\alpha$ dan $\beta$ zingiber, a kurkumen, fernesen, seskuiterpen, alkohol, $\mathrm{C}_{10}$ dan $\mathrm{C}_{9}$ aldehid. Rimpang jahe mengandung nutrisi (gizi) yang cukup tinggi.

Substansi kimia yang dapat menimbulkan rasa pedas dalam rongga mulut disebabkan oleh oleoresin dari jahe merah. Jahe merah juga mengandung minyak atsiri yang dapat memberi aroma tajam sehingga dapat meningkatkan kecepatan sekresi saliva dan meningkatkan $\mathrm{pH}$ saliva. $\mathrm{Hal}$ tersebut dibenarkan oleh penelitian yang telah dilakukan oleh Harahap, dkk (2017).

Sesuai dengan namanya, jahe merah atau jahe sunti ini berwarna kemerahan dengan aroma yang sangat tajam serta memiliki rasa yang paling pedas dibandingkan dengan kedua jahe jenis lainnya. Jenis jahe ini biasanya dimanfaatkan sebagai bahan baku obat-obatan herbal karena aroma dan rasanya terlalu tajam sehingga kurang cocok jika sebagai olahan makanan maupun sebagai campuran minuman hangat (Lestari, 2017).

Minyak atsiri merupakan kandungan dari jahe, dimana minyak atsiri tersebut dapat memberikan aroma tajam yang dapat meningkatkan laju aliran saliva. Potential of 
Hydrogen $(\mathrm{pH})$ berbanding lurus dengan laju aliran saliva, jika laju aliran saliva meningkat maka $\mathrm{pH}$ saliva pun akan meningkat (Harahap dkk, 2017). Saat berkumur dengan larutan jahe merah, minyak atsiri memberikan rangsangan. Refleks saliva yang terjadi sewaktu adanya kemoreseptor di dalam rongga mulut berespon terhadap adanya berbagai bentuk fisik makanan baik dalam bentuk padat maupun larutan. Ketika diaktifkan, reseptor-reseptor tersebut memulai impuls di serat aferen yang akan diteruskan ke pusat saliva medula oblongata. Impuls akan diteruskan melalui saraf parasimpatis ke pusat saliva dari nukleus salivatoris superior dan inferior di medula oblongata yang diketahui dapat meningkatkan sekresi saliva. Nukleus salivarius superior akan meneruskan impuls ke kelenjar submandibula dan sublingual, nukleus salivarius inferior akan meneruskan impuls ke kelenjar parotis sehingga jumlah saliva meningkat (Yulia dkk, 2017).

Oleh karena itu, penulis juga tertarik untuk melakukan penelitian dengan menggunakan air rebusan jahe merah sebagai obat kumur. Serta untuk mengetahui perubahan $\mathrm{pH}$ saliva sebelum dan sesudah berkumur air rebusan jahe merah.

\section{METODE PENELITIAN}

Jenis penelitian yang dilakukan menggunakan metode penelitian deskriptif kuantitatif dengan metode eksperimen. Desain penelitian dengan pre post and post test group design yaitu pengukuran $\mathrm{pH}$ saliva sebelum dan sesudah berkumur air rembusan jahe merah. Penelitian ini dilakukan di Kel. Lompo Riaja, Kec. Tanete Riaja, Kab. Barru. Penelitian ini dilakukan pada bulan Januari 2019.

Populasi dalam penelitian ini diambil dari masyarakat Kel. Lompo Riaja, Kec. Tanete Riaja, Kab. Barru. Sampel dalam penelitian ini diambil secara purposive sampling oleh peneliti. Dimana masyarakat yang diambil sebagai sampel berjumlah 30 orang dan memenuhi kriteria. Sampel 30 orang dibagi menjadi 3 perlakuan masing-masing 10 orang (larutan jahe merah sebanyak 75 gram, 100 gram dan 125 gram). Adapun prosedur penelitian yaitu Sebelumnya sampel penelitian diinstruksikan untuk Tidak makan, memakan permen dan merokok 1 jam sebelum dilakukan penelitian. Sampel penelitian diinstruksikan meludah ke dalam wadah yang telah disediakan. Mengukur $\mathrm{pH}$ saliva sebelum berkumur. Mencatat $\mathrm{pH}$ saliva sebelum berkumur pada lembar pemeriksaan. Sampel penelitian diberikan masing-masing $30 \mathrm{ml}$ air rebusan jahe merah, kemudian diinstruksikan berkumur selama 30 detik. Setelah 30 detik, sampel membuang larutan kumurnya. Kemudian diinstruksikan menampung saliva di dalam rongga mulutnya, kemudian setelah itu sampel penelitian diminta meludah ke dalam wadah yang telah disediakan. Dilakukan pengukuran $\mathrm{pH}$ saliva 5 menit kemudian sesudah berkumur air rebusan jahe merah dengan menggunakan $\mathrm{pH}$ meter. Mencatat hasil pengukuran setelah berkumur pada lembar pemeriksaan. Melakukan pengolahan dan analisis data setelah semua data yang diperlukan terkumpul. Data hasil penelitian ini adalah data $\mathrm{pH}$ saliva yang yang dikumpulkan kemudian dimasukkan ke dalam file komputer dan disajikan dalam bentuk tabel dan grafik. Serta dilakukan analisa data dengan menggunakan Uji Paired T-test.

\section{HASIL PENELITIAN}

Penelitian ini menggunakan metode penelitian deskriptif kuantitatif dengan metode eksperimen. Desain penelitian dengan pre post and post test group design. Sampel terdiri dari 30 orang yang dibagi menjadi 3 kelompok perlakuan, yaitu kelompok perlakuan I (berkumur air rebusan jahe merah sebanyak 75 gram), kelompok perlakuan II (berkumur air rebusan jahe merah sebanyak 100 gram) dan kelompok perlakuan III (berkumur air rebusan 
jahe merah sebanyak 125 gram). Hasil dan grafik. Serta tabel hasil Uji Paired T-test. penelitian akan diuraikan dalam bentuk tabel

Tabel 1 Distribusi Karakteristik Sampel Penelitian Berdasarkan Jenis Kelamin

\begin{tabular}{|c|c|c|c|c|c|c|}
\hline \multirow{3}{*}{ Jenis Kelamin } & \multicolumn{2}{|c|}{$\begin{array}{c}\text { Jahe Merah } \\
(75 \text { gram) }\end{array}$} & \multicolumn{2}{c|}{$\begin{array}{c}\text { Jahe Merah } \\
(100 \text { gram) }\end{array}$} & \multicolumn{2}{c|}{$\begin{array}{c}\text { Jahe Merah } \\
\text { (125 gram) }\end{array}$} \\
\cline { 2 - 7 } & $\begin{array}{c}\text { Jumlah } \\
(\mathrm{n})\end{array}$ & $\begin{array}{c}\text { Persentase } \\
(\%)\end{array}$ & $\begin{array}{c}\text { Jumlah } \\
(\mathrm{n})\end{array}$ & $\begin{array}{c}\text { Persentase } \\
(\%)\end{array}$ & $\begin{array}{c}\text { Jumlah } \\
(\mathrm{n})\end{array}$ & $\begin{array}{c}\text { Persentase } \\
(\%)\end{array}$ \\
\hline Laki-laki & 3 & 30 & 1 & 10 & 1 & 10 \\
\hline Perempuan & 7 & 70 & 9 & 90 & 9 & 90 \\
\hline Total & 10 & 100 & 10 & 100 & 10 & 100 \\
\hline
\end{tabular}

Sumber: Data Primer, 2019

Tabel 1 menunjukkan bahwa pada kelompok perlakuan jahe merah 75 gram dengan sampel sebanyak 10 orang terdiri dari 3 orang $(30 \%)$ berjenis kelamin laki-laki dan 7 orang $(70 \%)$ berjenis kelamin perempuan.
Sedangkan pada kelompok perlakuan jahe merah 100 gram dan 125 gram masing-masing dengan sampel sebanyak 10 orang terdiri dari 1 orang $(10 \%)$ berjenis kelamin laki-laki dan 9 orang $(90 \%)$ berjenis kelamin perempuan.

Tabel 2. Distribusi pH Saliva pada Responden Sebelum dan Sesudah Berkumur Air Rebusan Jahe Merah (75 gram)

\begin{tabular}{|c|c|c|c|c|}
\hline \multirow{2}{*}{$\begin{array}{c}\text { Kriteria } \\
\text { pH Saliva }\end{array}$} & \multicolumn{2}{|c|}{ Sebelum Berkumur } & \multicolumn{2}{c|}{ Sesudah Berkumur } \\
\cline { 2 - 5 }$(\mathrm{n})$ & $\begin{array}{c}\text { Jumlah } \\
(\%)\end{array}$ & $\begin{array}{c}\text { Jumlah } \\
(\mathrm{n})\end{array}$ & $\begin{array}{c}\text { Persentase } \\
(\%)\end{array}$ \\
\hline Asam & 10 & 100 & 9 & 90 \\
\hline Netral & 0 & 0 & 1 & 10 \\
\hline Basa & 0 & 0 & 0 & 0 \\
\hline Jumlah & 10 & 100 & 10 & 100 \\
\hline
\end{tabular}

Sumber: Data Primer, 2019

Tabel 2 menunjukkan bahwa terdapat perubahan antara $\mathrm{pH}$ saliva sebelum dan sesudah berkumur air rebusan jahe merah (75 gram). Sebelum berkumur $\mathrm{pH}$ saliva yang termasuk kriteria asam sebanyak 10 responden (100\%), tidak ada $\mathrm{pH}$ saliva yang termasuk kriteria netral dan basa. Sedangkan sesudah berkumur terjadi perubahan $\mathrm{pH}$ saliva walaupun masih dalam kriteria asam sebanyak 9 responden (90\%) dan yang mengalami perubahan kriteria $\mathrm{pH}$ saliva dari asam ke netral sebanyak 1 responden (10\%). Tidak ada $\mathrm{pH}$ saliva responden yang termasuk kriteria basa.

Tabel 3. Distribusi pH Saliva pada Responden Sebelum dan Sesudah Berkumur Air Rebusan Jahe Merah (100 gram)

\begin{tabular}{|c|c|c|c|c|}
\hline \multirow{2}{*}{$\begin{array}{c}\text { Kriteria } \\
\text { pH Saliva }\end{array}$} & \multicolumn{2}{|c|}{ Sebelum Berkumur } & \multicolumn{2}{|c|}{ Sesudah Berkumur } \\
\cline { 2 - 5 } & $\begin{array}{c}\text { Jumlah } \\
(\mathrm{n})\end{array}$ & $\begin{array}{c}\text { Persentase } \\
(\%)\end{array}$ & $\begin{array}{c}\text { Jumlah } \\
(\mathrm{n})\end{array}$ & $\begin{array}{c}\text { Persentase } \\
(\%)\end{array}$ \\
\hline Asam & 10 & 100 & 0 & 0 \\
\hline Netral & 0 & 0 & 9 & 90 \\
\hline Basa & 0 & 0 & 1 & 10 \\
\hline Jumlah & 10 & 100 & 10 & 100 \\
\hline
\end{tabular}

\section{Sumber: Data Primer, 2019}

Tabel 3 menunjukkan bahwa terdapat perubahan antara $\mathrm{pH}$ saliva sebelum dan sesudah berkumur air rebusan jahe merah (100 gram). Sebelum berkumur $\mathrm{pH}$ saliva yang 
termasuk kriteria asam sebanyak 10 responden (100\%), tidak ada $\mathrm{pH}$ saliva yang termasuk kriteria netral dan basa. Sedangkan sesudah berkumur terjadi perubahan $\mathrm{pH}$ saliva, tidak terdapat responden yang mempunyai $\mathrm{pH}$ saliva dalam kriteria asam, serta sebanyak 9 responden $(90 \%)$ dalam kriteria netral dan 1 responden (10\%) dalam kriteria basa.

Tabel 4. Distribusi pH Saliva pada Responden Sebelum dan Sesudah Berkumur Air Rebusan Jahe Merah (125 gram)

\begin{tabular}{|c|c|c|c|c|}
\hline \multirow{2}{*}{$\begin{array}{c}\text { Kriteria } \\
\text { pH Saliva }\end{array}$} & \multicolumn{2}{|c|}{ Sebelum Berkumur } & \multicolumn{2}{c|}{ Sesudah Berkumur } \\
\cline { 2 - 5 } & $\begin{array}{c}\text { Jumlah } \\
(\mathrm{n})\end{array}$ & $\begin{array}{c}\text { Persentase } \\
(\%)\end{array}$ & $\begin{array}{c}\text { Jumlah } \\
(\mathrm{n})\end{array}$ & $\begin{array}{c}\text { Persentase } \\
(\%)\end{array}$ \\
\hline Asam & 10 & 100 & 0 & 0 \\
\hline Netral & 0 & 0 & 5 & 50 \\
\hline Basa & 0 & 0 & 5 & 50 \\
\hline Jumlah & 10 & 100 & 10 & 100 \\
\hline
\end{tabular}

Sumber: Data Primer, 2019

Tabel 4 menunjukkan bahwa terdapat perubahan antara $\mathrm{pH}$ saliva sebelum dan sesudah berkumur air rebusan jahe merah (125 gram). Sebelum berkumur $\mathrm{pH}$ saliva yang termasuk kriteria asam sebanyak 10 responden (100\%), tidak ada $\mathrm{pH}$ saliva yang termasuk kriteria netral dan basa. Sedangkan sesudah berkumur terjadi perubahan $\mathrm{pH}$ saliva, tidak terdapat responden yang mempunyai $\mathrm{pH}$ saliva dalam kriteria asam, serta sebanyak 5 responden $(50 \%)$ dalam kriteria netral dan 5 responden (50\%) dalam kriteria basa.

\section{PEMBAHASAN}

Dari hasil penelitian dengan judul perubahan $\mathrm{pH}$ saliva sebelum dan sesudah berkumur air rebusan jahe merah pada masyarakat di Kelurahan Lompo Riaja Kecamatan Tanete Riaja Kabupaten Barru, menunjukkan ada perbedaan $\mathrm{pH}$ saliva sebelum dan sesudah berkumur air rebusan jahe merah. Perubahan $\mathrm{pH}$ saliva yang terjadi sebelum dan sesudah berkumur air rebusan jahe merah disebabkan oleh berbagai faktor dalam rongga mulut. Adanya rangsangan sangat mempengaruhi kecepatan sekresi dan komposisinya (Sundoro, 2007). Kecepatan sekresi dipengaruhi oleh rangsangan seperti asam, manis, pahit dan pedas (Amerongen, 1991). $\mathrm{pH}$ saliva berbanding lurus dengan kecepatan sekresi saliva. Jika kecepatan sekresi meningkat maka $\mathrm{pH}$ saliva juga akan meningkat (Harahap dkk, 2017).

Pada 3 kelompok perlakuan (berkumur air rebusan jahe merah 75 gram, 100 gram dan 125 gram) diperoleh nilai Sig $0.000<0.05$ yang menunjukkan bahwa adanya perubahan yang signifikan antara sebelum dan sesudah perlakuan. Karena nilai Sig < 0.05 maka HO ditolak dan $\mathrm{H} 1$ diterima yang berarti bahwa ada perubahan $\mathrm{pH}$ saliva sebelum dan sesudah berkumur air rebusan jahe merah. Dimana $\mathrm{pH}$ saliva sesudah berkumur air rebusan jahe merah mengalami peningkatan dibandingkan sebelum berkumur air rebusan jahe merah. Dasar pengambilan keputusan dalam uji Paired $T$-test yaitu jika nilai $p<0.05$ maka $\mathrm{HO}$ ditolak dan $\mathrm{H} 1$ diterima. Dimana 0.05 merupakan nilai signifikansi.

Hal ini sejalan dengan penelitian sebelumnya yang dilakukan oleh Harahap, dkk (2017) bahwa air rebusan jahe merah dapat meningkatkan $\mathrm{pH}$ saliva. Saat berkumur air rebusan jahe merah akan terjadi rangsangan kimiawi dengan rasa pedas yang terkandung di dalam jahe merah. Substansi kimia yang dapat menimbulkan rasa pedas dalam rongga mulut disebabkan oleh oleoresin dari jahe merah. Jahe merah juga mengandung minyak atsiri yang dapat memberi aroma tajam sehingga dapat 
meningkatkan kecepatan sekresi saliva. Berdasarkan penelitian sebelumnya yang telah dilakukan oleh Yulia, dkk (2017) bahwa berkumur air rebusan jahe merah dapat meningkatkan laju aliran saliva.

Di antara 3 kelompok perlakuan, yang lebih besar mengalami peningkatan $\mathrm{pH}$ saliva yaitu kelompok perlakuan dengan jahe merah sebanyak 125 gram yang memperoleh nilai ratarata sebesar 0,42000. Semakin besar rangsangan yang diterima rongga mulut berupa rasa pedas, maka semakin meningkatkan kecepatan sekresi saliva. Hal ini sejalan dengan penelitian yang dilakukan oleh Yulia, dkk (2017). Dimana jika kecepatan sekresi saliva lebih meningkat maka $\mathrm{pH}$ saliva pun lebih besar mengalami peningkatan.

Kondisi asam dalam rongga mulut dapat dimanfaatkan oleh bakteri Steptococcus mutans untuk membentuk koloni yang dapat merusak lapisan gigi dan menyebabkan karies gigi. Salah satu komponen yang memberi kontribusi terhadap tingkat keasaman mulut adalah $\mathrm{pH}$ saliva. Saliva sebagai sistem penyangga untuk menjaga $\mathrm{pH}$ optimal mulut, yaitu $\mathrm{pH}$ yang cenderung basa (Kidd dan Bechal, 1991). Sehingga diperlukan cara untuk memelihara keseimbangan $\mathrm{pH}$ saliva dengan penggunaan obat kumur yang aman seperti dengan berkumur air rebusan jahe merah.

\section{KESIMPULAN DAN SARAN}

Berdasarkan dari hasil penelitian yang berjudul "Perubahan $\mathrm{pH}$ Saliva Sebelum dan Sesudah Berkumur Air Rebusan Jahe Merah Trilaksono dan Lia Walianti. 2015. Ekstraksi Minyak Atsiri Jahe Merah dengan Variasi Jenis Pelarut dan Waktu Ekstraksi. Seminar Nasional Teknologi. ISSN: 24-7 - 7534.

Gendrowati, Fitri. 2018. Tanaman Ajaib. Jakarta Timur: Pustaka Makmur.

Harahap, Rani Nurzaini, Ridha Andayani dan Abdillah Immron Nasution. 2017. Perubahan Portential of Hydrogen $(\mathrm{pH})$ Saliva Sebelum dan Sesudah Berkumur Air Rebusan Jahe Merah (Z. Officinale pada Masyarakat di Kelurahan Lompo Riaja Kecamatan Tanete Riaja Kabupaten Barru" dapat disimpulkan bahwa ada perubahan $\mathrm{pH}$ saliva sebelum dan sesudah berkumur air rebusan jahe merah. Dimana $\mathrm{pH}$ saliva sesudah berkumur air rebusan jahe merah mengalami peningkatan dibandingkan $\mathrm{pH}$ saliva sebelum berkumur air rebusan jahe merah. Terdapat perubahan $\mathrm{pH}$ saliva sebelum dan sesudah berkumur air rebusan jahe merah sebanyak 75 gram. Perubahan $\mathrm{pH}$ saliva sebelum dan sesudah berkumur air rebusan jahe merah sebanyak 100 gram. Perubahan $\mathrm{pH}$ saliva sebelum dan sesudah berkumur air rebusan jahe merah sebanyak 125 gram.

Berdasarkan hasil penelitian yang telah dilakukan maka peneliti memberikan saran agar masyarakat tetap menjaga kesehatan gigi dan mulutnya dengan memeriksakan giginya ke dokter gigi atau perawat gigi secara berkala 6 bulan sekali. Peneliti juga menyarankan agar memilih obat kumur yang kurang mengandung bahan kimia seperti alkohol. Salah satunya dengan cara berkumur menggunakan air rebusan jahe merah yang merupakan obat kumur alami. Kandungan jahe merah seperti minyak atsiri dan oleoresin dapat meningkatkan kecepatan sekresi saliva sehingga $\mathrm{pH}$ saliva juga mengalami peningkatan.

\section{DAFTAR PUSTAKA}

Amerongen, A. Van Niew, L.F.E. Michels, P.A. Roukema dan E.C.I. Veerman. 1991. Ludah dan Kelenjar Ludah. Yogyakarta: Gadjah Mada University Press.

Daryono, Elvianto Dwi, Ferry Andri

var Rubrum) Pada Mahasiswa Fakultas Kedokteran Gigi Universitas Syiah Kuala Angkatan 2016. Journal Caninus Dentistry. 2(3). 117-120.

Kasuma, Nila. 2015. Fisiologi dan Patologi Saliva. Padang: Andalas University Press.

Kidd, Edwina A.M. dan Sally Joy-Bechal. 1991. Dasar-dasar Karies Penyakit dan Penanggulangannya. Jakarta: EGC.

Kusumawardani, Chendrakasih, Michael A. Leman dan Christy N. Mintjelungan. 
2017. Pengaruh Air Kelapa terhadap Peningkatan $\mathrm{pH}$ Saliva. Jurnal e-GiGi (eG). 5(1).

Lestari, Nutri. 2017. Sukses Budidaya Jahe. Yogyakarta: Oryza.

Manson J.D, B.M. Eley. 1993. Buku Ajar Periodonti. Jakarta: Hipokrates.

Maryati. 2000. Derajat Keasaman $(\mathrm{pH})$ saliva pada Rongga Mulut Berkaries dan Tidak Berkaries [skripsi]. Medan (ID): Universitas Sumatera Utara.

Pramudya, Adi. 2018. Budidaya dan Bisnis Jahe. Jakarta: PT. AgroMedia Pustaka.

Rezkiah, Prima. 2008. Perbedaan pH saliva antara Penderita dan yang Bukan Penderita Diabetes Melitus Ditinjau dari Beberapa Faktor [skripsi]. Makassar (ID) : Universitas Hasanuddin.

Sari, Dian Novita, Cholil dan Bayu Indra Sukmana. 2014. Perbandingan Efektifitas Obat Kumur Bebas Alkohol yang Mengandung Cetylpyridinium Chloride dengan Chlorhexidine terhadap Penurunan Plak. Dentino Jurnal Kedokteran Gigi. 2, 179 - 183.
Setyaningrum, Hesti Dwi dan Cahyo Saparitno. 2016. Jahe. Jakarta: Penebar Swadaya

Setyawan, Budi. 2015. Peluang Usaha Budidaya Jahe. Yogyakarta: Pustaka Baru Press.

Situmeang, Tesalonika Pratiwi. 2017. Efektivitas Berkumur larutan Air Kemasan Alkaline lonized Water (IAW) terhadap perubahan $\mathrm{pH}$ dan Jumlah Koloni Bakteri dalam Saliva [skripsi]. Makassar (ID) : Universitas Hasanuddin.

Sundoro, Edi Hartini. 2007. Serba-serbi IImu Konservasi Gigi. Jakarta: UI-Press.

Tarigan, Rasinta. 2016. Karies Gigi. Jakarta: EGC.

Yulia, Niken, Ridha Andayani, Abdillah Imron Nasution. 2017. Perubahan Laju Aliran Saliva Sebelum dan Sesudah Berkumur Rebusan Air Jahe Merah (Zingiber officinale var. Rubrum) Pada Mahasiswa FKG Unsyiah Angkatan 2016. Journal Caninus Dentistry. 2(3). 104 - 110. 